НАУКОВИЙ ВІСНИИК

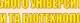

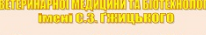

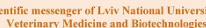

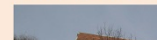

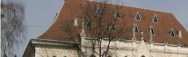
11) MIMMN H. 19 तst if СЕРі: ХАРчОВ технолог ERRIS: FOOD T
Науковий вісник Дьвівського національного університету ветеринарної медицини та біотехнодогій імені С.3. Гжицького. Серія: Харчові технології

\section{Scientific Messenger of Lviv National University} of Veterinary Medicine and Biotechnologies.

Series: Food Technologies doi: 10.32718/nvlvet-f9614

https://nvlvet.com.ua/index.php/food

UDC 664:663.9

\title{
Features of application of biologically valuable vegetable raw materials of Skolivschina in galician cuisine dishes preparation
}

\author{
M. Ya. Bomba ${ }^{1}$, S. V. Maykova ${ }^{1}$, I. S. Romashko ${ }^{2}$, N. P. Shemedyuk ${ }^{2}$ \\ ${ }^{1}$ Ivan Franko National University Lviv, Ukraine \\ ${ }^{2}$ Stepan Gzhytskyi National University of Veterinary Medicine and Biotechnologies Lviv, Ukraine
}

Article info

Received 26.05.2021

Received in revised form 28.06 .2021 Accepted 29.06.2021

Ivan Franko National University of Lviv. Kyryla i Mefodiya Str., 6, Lviv, 79005, Ukraine.

Stepan Gzhytskyi National University of Veterinary Medicine and Biotechnologies Lviv, Pekarska str., 50, Lviv, Ukraine. Tel.: +38-050-579-04-99 E-mail:mysh@ukr.net
Bomba, M. Ya., Maykova, S. V., Romashko, I. S., \& Shemedyuk, N. P. (2021). Features of application of biologically valuable vegetable raw materials of Skolivschina in galician cuisine dishes preparation. Scientific Messenger of Lviv National University of Veterinary Medicine and Biotechnologies. Series: Food Technologies, 23(96), 82-87. doi: 10.32718/nvlvet-f9613

The paper considers the peculiarities of the non-traditional vegetable raw materials of Skolivshchyna in the production of Galician cuisine with health-improving properties. We studied the experience of scientists in improving the quality of food and increasing their biological value through the addition of functional plant materials. The authors of the article described the results of the improvement of three dishes of Ukrainian cuisine, in the recipes of which there are non-traditional vegetable raw materials of high nutritional and biological value. This is a characteristic feature of modern trends in the food industry, which supports the main trends of rational and healthy eating and allows you to adapt traditional Ukrainian dishes to the consumer preferences of today's residents. The publication substantiates the use of Agropyrum repens, Urtica dioica L. and Oxalis acetosella as raw components of updated dishes. The aim of the work was to improve the technology of cooking Galician cuisine with partial replacement of several traditional recipe components. The research was conducted on the basis of the Department of Hotel and Restaurant Business and Food Technologies of Ivan Franko Lviv National University. The raw materials used met the quality and safety requirements of current regulations.

Key words: Ukrainian cuisine, Agropyrum repens, Urtica dioica L., Oxalis acetosella, biological and energy value.

\section{Особливості застосування біологічно цінної рослинної сировини Сколівщини у виготовленні страв галицької кухні}

\author{
М. Я. Бомба ${ }^{1}$, С. В. Майкова ${ }^{1}$, I. С. Ромашко ${ }^{2}$ Н. П. Шемедюк ${ }^{2}$ \\ ${ }^{1}$ Львівський національний університет імені І. Франка, м. Львів, Украӥна \\ ${ }^{2}$ Львівський національний університет ветеринарної медицини та біотехнологій імені С. 3. Гжицького, м. Львів, \\ Україна
}

У роботі розглянули особливості застосування нетрадиційної рослинної сировини Сколівщини при виготовленні страв галицької кухні з оздоровчими властивостями. Вивчено досвід науковців щчодо поліпшення показників якості страв та підвищення їхньої біологічної цінності через додавання функціональної рослинної сировини. В статті описано результати удосконалення трьох страв украӥнської кухні, в рецептури яких внесена нетрадичійна рослинна сировина високої харчової та біологічної иінності, щуо є характерною особливістю сучасних тенденцій розвитку раціонального та оздоровчого харчування у харчовій індустрії та дозволяє адаптувати традичійні українські страви до спожсичих уподобань. У публікаиї обтрунтовано використання кропиви дводомної, пирію повзучго та щуавлю заячого як нетрадиційних сировинних компонентів оновлених рецептур страв. Метою роботи стало удосконалення технології приготування страв галицької кухні з частковою заміною кількох традиційних рецептурних компонентів. Дослідження проводили на базі кафедри готельно-ресторанної справи та 
харчових технологій ЛНУ імені І. Франка. Використана сировина відповідала за якістю $і$ безпечністю вимогам діючої нормативної документаиії.

Ключові слова: украйнська кухня, кропива дводомна, пирій повзучий, щуавель заячий, біологічна та енергетична цүінність.

Вступ

Сучасні світові стратегії розвитку харчової сфери часто передбачають коригування інгредієнтного складу продуктів харчування та розширення асортиментного ряду продукції шляхом внесення нетрадиційної, але цінної в біологічному та харчовому сенсі сировини в рецептури страв, традиційних для певної місцевості. Такий підхід покликаний зменшити негативні наслідки зміни способу харчування, що відбуваються в нашому “швидкому” світі. Найбільш ефективним і доцільним з економічної, соціальної, гігієнічної й технологічної точок зору поступом у цьому напрямку є розробка та створення функціональних харчових продуктів, додатково збагачених вітамінами, макро- та мікроелементами до рівня, що відповідає фізіологічним потребам людини. При цьому для профілактики та оздоровлення великої кількості споживачів важливими насамперед виступають якість та доступність асортименту продукції (Halukh et al., 2020; Basarab et al., 2021; Hachak et al., 2021).

Актуальність теми. Для нормальної життєдіяльності людини іiі раціон харчування, враховуючи індивідуальні особливості, характер та інтенсивність роботи, а також умови проживання, повинен в оптимальному співвідношенні містити необхідні компоненти (білки рослинного й тваринного походження, жири, вуглеводи, вітаміни, мікро - та макроелементи тощо) (Dudenko, 2017). Особливу нішу займають продукти органічного походження, до яких належать зокрема дикоростучі рослини, а також їхні культурні представники, вирощені в господарствах, що спеціалізуються на виробнцтві екологічно чистої сировини. Дикоростучі харчові рослини характеризуються особливим неповторним комплексом вітамінів, білкових сполук, жирних та органічних кислот, мікроелементів та біологічно активних речовин. Це підтверджено численними дослідженнями вітчизняних і зарубіжних учених, що описують лікувальні та профілактичні властивості такої сировини (Harna, 2016). Харчова рослинна сировина - це джерело біологічно активних сполук, які навіть в мінімальній кількості позитивно впливають на організм людини.

Останнім часом людство помітно страждає від одноманітності їжі за певними показниками, внаслідок чого наш організм втрачає встановлену рівновагу з зовнішнім середовищем, що загрожує погіршенням стану здоров'я. Щоб цьому запобігти, необхідно, до прикладу, вже ранньою весною доповнювати свій раціон свіжою зеленню. Молоді частини дикорослих рослин: проростки i пагони, листя і коріння, бульби і цибулини є відмінною їжею як самі по собі, так і в суміші з різними овочами в салатах, а також перших та других стравах.

Карпатська флора, як i традиційні страви мешканців цих територій, завжди дивували своїм різноманіттям та несли позитивний вплив на організм людини. Цілющі властивості багатьох рослин Карпатського краю давно відомі, але можливості їх поєднання безмежні (Maikova et al., 2021). Тому вивчення особливостей використання органічної рослинної сировини Сколівщини в рецептурах галицьких страв $є$ актуальною темою досліджень.

\section{Матеріал і методи досліджень}

Для досягнення поставленої мети, а саме створення оновлених рецептур галицьких страв, використовували пошуково-дослідницькі, аналітичні, розрахункові та органолептичні методи, а також методи порівняльного аналізу. Об' $є к т о м ~$ дослідження було застосування дикоростучої рослинної сировини у технології приготування страв iз оздоровчими властивостями. Предметом дослідження стало удосконалення асортименту страв оздоровчого спрямування із використанням нетрадиційної рослинної сировини Сколівщини (Maikova \& Bomba, 2020; Maikova et al., 2020). Для дослідження впливу та корисності страв оздоровчого спрямування використовували пирій повзучий, кропиву дводомну та щавель заячий.

Пирій повзучий (Agropyrum repens) - один 3 найпоширеніших бур'янів, але в ньому міститься значна кількість цінних речовин: каротин, аскорбінова та яблучна кислоти, білки, вуглеводи, ефірна олія i, що дуже цінно, кремній, який сприяє утриманню і засвоєнню в організмі кальцію. Основна лікувальна властивість пирію - це його здатність “очищати” кров і організм загалом від токсинів, він корисний при гепатиті й захворюваннях жовчовивідних шляхів. Високий вміст вітамінів, мінералів і кремнію робить пирій незамінним засобом для лікування нервових захворювань. 3 кореневищ пирію повзучого часто виготовляють борошно, а листки та суцвіття використовують при виготовленні напоїв, відварів, у салатах та інших стравах (Volkova, 2015).

Кропива (Urtica dioica L.) - багаторічна трав'яниста дводомна рослина 3 повзучим кореневищем. Листя кропиви завжди асоціювалось 3 приготуванням здорової, вітамінізованої їжі. Це свіжі салати, яєчні, зелені борщі, засоли, навіть соки. Особливо корисний ранньої весни свіжий сік кропиви. Корисна кропива при анемії, оскільки підвищує гемоглобін, збільшує кількість еритроцитів у крові. Вживання свіжого листя кропиви знижує кількість цукру в крові, що так важливо для діабетиків (Zhohlo, 1992).

Щавель заячий (Oxalis acetosella) - це трав’яниста багаторічна лікарська рослина, що належить до квасеницевих. Відома 3 народної кулінарії як смачна приправа до смаженої риби і лісового салату. Рослина 
містить рутин, каротин, аскорбінову кислоту, флавоноїд орієнтин, а також бурштинову, яблучну і щавлеву кислоти. Листки додають до різноманітних страв, ними посипають смажене м'ясо i яєчні, змішують 3 салатами, вживають 3 сиром, ковбасою, паштетами і бутербродами. Це не лише поліпшує смак їжі, а й підвищує опірність організму до шкірних захворювань, атеросклерозу, печії у шлунку, нефритів, жовтяниці, захворювань сечового міхура. Заячий щавель допомагає при отруєнні організму важкими металами.

\section{Результати та їх обговорення}

Першою стравою, яку обрали як основу для вдосконалення, є “Салат 3 білокачанної капусти 3 яблуком та селерою”. Для приготування традиційної страви використовують білокачанну капусту, яблуко, селеру, цукор, оливкову олію, кунжут. Для удосконалення страви як інноваційні інгредієнти запропоновано включити у рецептуру кропиву дводомну та щавель заячий (табл. 1).

Салати завжди посідали важливе місце в українській кухні. Вони працюють на збудження апетиту перед споживанням основних страв (це також пояснює порядок подачі їх до столу). Салати основне джерело натуральних вітамінів і мінеральних речовин. Ароматичні, забарвлюючі та смакові компоненти рослинної сировини стимулюють травну систему до роботи. Також для приготування салатів варто віддавати перевагу зелені, в нашому випадку дикоростучій. Кропива дводомна та пирій повзучий позитивно впливають на печінку, очищують кров, підвищують кількість еритроцитів. Тому дуже важливо включати цю сировину в раціон.

\section{Таблиця 1}

Рецептура салату "Вітамінний”

\begin{tabular}{lcc}
\hline \multicolumn{1}{c}{$\begin{array}{c}\text { Найменування } \\
\text { продуктів }\end{array}$} & \multicolumn{2}{c}{ Норма закладки на 1 порцію } \\
\cline { 2 - 3 } Капуста білокачанна & 60 & нетто, г \\
Яблуко & 42 & 60 \\
Селера & 28 & 31 \\
Цукор & 6 & 20 \\
Кунжут & 3 & 6 \\
Оливкова олія & 5 & 3 \\
Кропива дводомна & 15 & 5 \\
Пирій повзучий & 10 & 15 \\
Вихід (нетто) & \multicolumn{2}{c}{10} \\
\hline
\end{tabular}

Різниця між технологією оригінальної рецептури салату та експериментальної в додаванні листя кропиви та пирію. Їх ошпарюють кип'ятком та подрібнюють. Результати проведеної органолептичної оцінки салату "Вітамінний” та порівняльний аналіз його харчової і біологічної цінності, що наведені у табл. 2 і 3, підтверджують відповідність запропонованої рецептури вимогам щодо якості продуктів та страв харчування.

\section{Таблиця 2}

Органолептична оцінка показників якості салату "Вітамінний"

\begin{tabular}{lc}
\hline \multicolumn{1}{c}{ Показник } & Оцінка \\
\hline Зовнішній вигляд & 5 \\
Колір & 5 \\
Смак & 5 \\
Запах & 4,8 \\
Загальна оцінка & 4,95 \\
\hline
\end{tabular}

\section{Таблиця 3}

Порівняльна характеристика харчової та біологічної цінності салатів

\begin{tabular}{|c|c|c|}
\hline \multirow[b]{2}{*}{$\begin{array}{c}\text { Найменування } \\
\text { показника }\end{array}$} & \multicolumn{2}{|c|}{ Вміст поживних речовин } \\
\hline & $\begin{array}{c}\text { Салат з білокачанної } \\
\text { капусти з яблуком та } \\
\text { селерою }\end{array}$ & $\begin{array}{c}\text { Салат } \\
\text { Вітамін- } \\
\text { ний }\end{array}$ \\
\hline Калорійність, ккал & 127,95 & 148,3 \\
\hline Білки, г & 2,40 & 1,70 \\
\hline Жири, г & 7,50 & 9,20 \\
\hline Вуглеводи, г & 13,50 & 4,10 \\
\hline Вітамін $\mathrm{B}_{1}$ (тіамін), мг & 0,045 & 0,09 \\
\hline $\begin{array}{l}\text { Вітамін В } \\
\text { (рибофлавін), мг }\end{array}$ & 0,06 & 0,12 \\
\hline $\begin{array}{l}\text { Вітамін В } \\
\text { (пантотенова к-та), мг }\end{array}$ & 0,30 & 0,36 \\
\hline $\begin{array}{l}\text { Вітамін В9 (фолієва } \\
\text { к-та), мкг }\end{array}$ & 12,90 & 15,00 \\
\hline Залізо, мг & 1,50 & 3,80 \\
\hline Йод, мкг & 3,90 & 5,00 \\
\hline Кальцій, мг & 70,95 & 64,50 \\
\hline Магній, мг & 27,60 & 11,90 \\
\hline Харчові волокна, г & 3,45 & 7,00 \\
\hline
\end{tabular}

Згідно 3 результатами порівняльної характеристики досліджуваних салатів, можна стверджувати, що в експериментальному варіанті салату 3 використанням нетрадиційної рослинної сировини міститься менше білків і вуглеводів, ніж у початковому варіанті салату, але значно більший вміст жиру та мікроелементів, зокрема заліза, йоду, а також вітамінів: $\mathrm{B}_{1}, \mathrm{~B}_{2}, \mathrm{~B}_{5}$ та $\mathrm{B}_{9}$. Салат "Вітамінний" характеризується високою енергетичною цінністю, яка на 20,35 \% вища, ніж у зразку порівняння. Тому такий салат буде дуже корисний для людей, робота яких потребує тривалої концентрації, при хронічних захворюваннях та для загального зміцнення здоров'я.

Наступною стравою, обраною для вдосконалення, $\epsilon$ перша страва - "Розсольник домашній” із інгредієнтами: крупа рисова, картопля, м'ясо, морква, цибуля, огірок солений та розсіл. Розсольник - рідка страва, яка стала традиційною у багатьох країнах, в тому числі й в Україні. Обов'язковим складником його є солоні огірки.

При створенні експериментального варіанту (Розсольник львівський) запропоновано використати в рецептурі цієї страви кілька нетрадиційних компонентів, а саме кропиву дводомну i щавель заячий (табл. 4). У сукупності вони постають потужним засобом у боротьбі з проблемами нирок, які зараз, на жаль, дуже часто виявляють уже в молодому віці. Різниця між технологією виготовлення 
оригінальної рецептури розсольника та експериментальної в додаванні листя кропиви та щавлю.

\section{Таблиця 4}

Рецептура розробленої страви "Розсольник львівський"

\begin{tabular}{lcc}
\hline \multicolumn{1}{c}{ Найменування } & \multicolumn{2}{c}{ Порма закладки на 4 порції } \\
\cline { 2 - 3 } \multicolumn{1}{c}{ продув } & брутто, г & нетто, г \\
\hline Крупа рисова & 90 & 120 \\
Картопля & 160 & 135 \\
Морква & 50 & 40 \\
Цибуля & 36 & 33 \\
Огірок солоний & 70 & 65 \\
Розсіл & 250 & 200 \\
М'ясо (свинина) & 250 & 180 \\
Кропива дводомна & 17 & 17 \\
Щавель заячий & 10 & 10 \\
Вода & 400 & 200 \\
Вихід & 1333 & 1000 \\
\hline
\end{tabular}

Відповідність даної рецептури вимогам якості продуктів i страв харчування підтверджено результатами проведеної органолептичної оцінки (табл. 5) та порівняльною характеристикою харчової та біологічної цінності контрольної та експериментальної страв (табл. 6).

Аналіз отриманих даних дозволяє стверджувати, що використання листків кропиви дводомної та щавлю заячого у приготуванні "Розсольнику львівського" значно підвищує харчову та біологічну цінність страви. Зазначимо, що в розсольнику львівському вміст вуглеводів був на 2,52 мг вищим порівняно 3 розсольником домашнім. Тенденцію зростання видно у вмісті білків (на 0,57 г) та значенні калорійності (на 1,27 г), але водночас вміст жирів зменшився на 1,95 г. Спостерігається ріст значень вмісту в страві вітамінів $\mathrm{B}_{1}, \mathrm{~B}_{2}, \mathrm{~B}_{5}, \mathrm{~B}_{6}, \mathrm{C}$ та мікроелементів.

Ще одною базовою стравою для внесення в іï рецептуру нетрадиційних компонентів стала друга страва - "Куряче філе з грибами та сиром". Для іiі приготування потрібно: куряче філе, печериці, сир твердий, яйце куряче, борошно, сіль та перець. 3 метою поліпшення оздоровчих властивостей страви, замість сиру використали пирій повзучий, а нову страву назвали “Куряче філе по-галицьки”.

В експериментальному зразку (табл. 7) замінили сир твердий, який містить значний відсоток жиру (4555 \%), на листя пирію повзучого та борошна 3 пирію. Оскільки для приготування експериментальної страви необхідне борошно, то використали борошно, виготовлене $з$ кореневища пирію повзучого (висушені природним шляхом сухі подрібнені частини кореневища розтирали за допомогою подрібнювача). Вихід готової страви дещо змінився, але незначно. В стандартному зразку вихід дорівнював 200 г, а в експериментальному становив 180 г.

Результати проведеної органолептичної оцінки (табл. 8) свідчать про відповідність даної рецептури вимогам якості продуктів та страв харчування.
Таблиця 5

Органолептична оцінка страви "Розсольник львівський”

\begin{tabular}{lc}
\hline \multicolumn{1}{c}{ Показники } & "Розсольник львівський” \\
\hline Зовнішній вигляд & 4,9 \\
Колір & 5 \\
Смак & 4,9 \\
Запах & 5 \\
Загальна оцінка & 4,95 \\
\hline
\end{tabular}

\section{Таблиця 6}

Порівняльна характеристика харчової та біологічної цінності страв

\begin{tabular}{|c|c|c|}
\hline \multirow[b]{2}{*}{ Найменування показника } & \multicolumn{2}{|c|}{ Вміст поживних речовин } \\
\hline & $\begin{array}{l}\text { "Розсольник } \\
\text { домашній" }\end{array}$ & $\begin{array}{l}\text { “Розсольник } \\
\text { львівський” }\end{array}$ \\
\hline Калорійність, ккал & 96,00 & 97,27 \\
\hline Білки, г & 2,25 & 2,82 \\
\hline Жири, г & 4,00 & 3,05 \\
\hline Вуглеводи, г & 13,50 & 15,52 \\
\hline Вітамін В1 (тіамін), мг & 0,10 & 0,30 \\
\hline Вітамін В2 (рибофлавін), мг & 0,075 & 0,087 \\
\hline Вітамін В5 (пантотенова), мг & 0,225 & 0,280 \\
\hline Вітамін В6 (піридоксин), мг & 0,25 & 0,31 \\
\hline Вітамін С, мГ & 13,75 & 14,00 \\
\hline Залізо, мг & 1,00 & 1,28 \\
\hline Йод, мкг & 4,00 & 8,45 \\
\hline Калій, мг & 531,25 & 698,15 \\
\hline Кальцій, мг & 47,25 & 46,90 \\
\hline Кобальт, мкг & 4,00 & 6,70 \\
\hline Магній, мг & 28,25 & 31,80 \\
\hline Натрій, мг & 26,75 & 25,87 \\
\hline Харчові волокна, г & 2,75 & 3,05 \\
\hline Сірка, мг & 31,75 & 32,60 \\
\hline Фосфор, мг & 69,00 & 75,32 \\
\hline
\end{tabular}

\section{Таблиця 7}

Рецептура розробленої страви “Куряче філе погалицьки"

\begin{tabular}{lcc}
\hline \multirow{2}{*}{ Найменування продуктів } & \multicolumn{2}{c}{ Норма закладки на 1 порцію } \\
\cline { 2 - 3 } & Брутто, г & Нетто, г \\
\hline Куряче філе & 150 & 150 \\
Печериці & 35 & 27 \\
Яйце куряче & 1 шт. & 40 \\
Борошно (пирій повзучий) & 10 & 10 \\
Пирій повзучий & 7 & 7 \\
Сіль & 3 & 3 \\
Перець & 2 & 2 \\
Вихід & & 180 \\
\hline
\end{tabular}

\section{Таблиця 8}

Органолептична оцінка страви “Куряче філе по-галицьки"

\begin{tabular}{lc}
\hline \multicolumn{1}{c}{ Показники } & Кількість балів \\
\hline Зовнішній вигляд & 5 \\
Колір & 5 \\
Смак & 5 \\
Запах & 5 \\
Загальна оцінка & 5 \\
\hline
\end{tabular}


Результати органолептичної оцінки показали, що 3 доданням рослинної сировини до рецептури "Курячого філе з грибами та сиром" покращився зовнішній вигляд та смак нової страви, що підвищує значення загальної оцінки.

3 порівняльної характеристики двох страв (основної та зміненої рецептури) (табл. 9) видно, що у варіанті експериментального зразка міститься менше білка, жиру, ніж у початковому, але зростає вміст вуглеводів, вітамінів і харчових волокон. Також спостерігали позитивну тенденцію щодо підвищення вмісту мікроелементів, зокрема заліза на 0,6 г, йоду на 1,2 г, калію на 14,2 г та деяких інших. Калорійність страви для курячого філе по-галицьки була вищою, ніж для курячого філе з грибами та сиром на 9,6 \%.

\section{Таблиця 9}

Аналіз харчової та біологічної цінності курячого філе за різної рецептури приготування

\begin{tabular}{lcc}
\hline & \multicolumn{2}{c}{ Вміст поживних речовин у } \\
\cline { 2 - 3 } Нтраві & \multicolumn{2}{c}{ Найменування показника “Куряче філе 3 “Куряче філе } \\
& $\begin{array}{c}\text { грибами та } \\
\text { сиром” }\end{array}$ & по-галицьки” \\
\hline Калорійність, ккал & 452,4 & 462 \\
Білки, г & 26,8 & 18,88 \\
Жири, г & 38 & 24,2 \\
Вуглеводи, г & 1 & 2,3 \\
Вітамін В1 (тіамін), мг & 0,12 & 0,2 \\
Вітамін В12 (кобаламін), мкг & 0,8 & 0,91 \\
Вітамін В (рибофлавін), мг & 0,4 & 0,46 \\
Вітамін В5 (пантотенова), мг & 1,6 & 2,2 \\
Вітамін В6 (піридоксин), мг & 0,8 & 1 \\
Вітамін В9 (фолієва), мкг & 13,6 & 15 \\
Залізо, мг & 4,4 & 5 \\
Йод, мкг & 12,8 & 14 \\
Калій, мг & 405,4 & 419,6 \\
Кальцій, мг & 45,8 & 31,5 \\
Кобальт, мкг & 21,2 & 22 \\
Магній, мг & 41,2 & 36,7 \\
Харчові волокна, г & 6,4 & 8,3 \\
Фосфор, мг & 346,8 & 289,1 \\
\hline
\end{tabular}

\section{Висновки}

Враховуючи результати, описані вище, можна узагальнити, що дослідження, пов'язані з пошуком інгредієнтних альтернатив для традиційних страв національних кухонь є завжди цікавими і творчими. Експериментально вивчено показники якості кількох страв галицької кухні, а саме "Салату з білокачанної капусти 3 яблуком та селерою”, “Розсольника домашнього" і “Курячого філе з грибами та сиром". Підтверджено можливість включення до їх рецептури не нових, але нетрадиційних для обраних страв, компонентів, таких як кропива дводомна, пирій повзучий та щавель заячий. Запропоновано оновлені страви “Салат вітамінний”, “Розсольник львівський” і “Куряче філе по-галицьки”, проаналізовано їхні органолептичні показники, харчову та біологічну цінність. Удосконалені рецептури страв відзначені високими оцінками їнніх смакових властивостей без ускладнення технології приготування, характеризуються високим вмістом енергетично цінних та біологічно активних речовин.

Враховуючи проаналізовані корисні властивості страв, приготованих 3 використанням нетрадиційної рослинної сировини місцевого походження, а саме Сколівщини, можна рекомендувати їх до впровадження в меню закладів ресторанного господарства, що в кінцевому результаті позитивно вплине на поліпшення здоров'я споживачів, розвиток туристичного бізнесу Карпатського регіону та розширить асортимент пропонованих гастрономічних принад.

\section{References}

Basarab, I., Drachuk, U., Halukh, B., Koval, H., Simonova, I., \& Herez, N. (2021). Using of nontraditional raw materials in the technology of cooked sausages with functional purposes. Scientific Messenger of LNU of Veterinary Medicine and Biotechnologies. Series: Food Technologies, 23(95), 65-71. doi: 10.32718/nvlvet-f9511.

Cherevko, O. I., Peresichnyi, M. I., \& Tiurikova, I. S. (2017). Innovatsiini tekhnolohii produktsii funktsionalnoho pryznachennia. Monohrafiia. Kharkiv, KhDUKhT. URL: http://dspace.puet.edu.ua/handle/123456789/8491 (in Ukrainian).

Dudenko, N. V. (2017). Ocnovy fiziolohii kharchuvannia: navchalnyi posibnyk: KhDUKhT (in Ukrainian).

Hachak, Y., Nahovska, V., \& Gutyj, B. (2021). The use of cryopowder from seafood in the technology of thermostatic yogurt for therapeutic and prophylactic purposes. Scientific Messenger of LNU of Veterinary Medicine and Biotechnologies. Series: Food Technologies, 23(95), 83-90. doi: 10.32718/nvlvet-99514.

Halukh, B., Drachuk, U., Simonova, I., Basarab, I., \& Romashko, I. (2020). Expanding the range of sausage products of special purpose. Scientific Messenger of LNU of Veterinary Medicine and Biotechnologies. Series: Food Technologies, 22(94), 37-43. doi: 10.32718/nvlvet-f9408.

Harna, S. V., Vladymyrova, I. M., \& Burd, N. B. (2016). Suchasna fitoterapiia. Navchalnyi posibnyk. Kharkiv (in Ukrainian).

Maikova, S. V., \& Bomba, M. Ia. (2020). Vykorystannia netradytsiinoi syrovyny dlia pryhotuvannia farshiv. Kharchovi dobavky. Kharchuvannia zdorovoi ta khvoroi liudyny: materialy IKh Mizhnarodnoi nauk.prakt. internet-konf. Praha: Oktan Print s.r.o., 174-176 (in Ukrainian).

Maikova, S. V., Vivcharuk, O. M., \& Romashko, I. S. (2020). Udoskonalennia natsionalnykh strav ta yikh adaptatsiia dlia suchasnykh zakladiv restorannoho hospodarstva. Visnyk Lvivskoho instytutu ekonomiky i turyzmu: zb. nauk. st., 15, 120-129 (in Ukrainian).

Maikova, S. V., Vivcharuk, O. M., Bomba, M. Ia. (2021). Perspektyvy vyhotovlennia strav iz profilaktychnymy vlastyvostiamy vvedenniam netradytsiinoi syrovyny. Zhurnal "Innovatsii ta tekhnolohii $\mathrm{v}$ sferi posluh $\mathrm{i}$ kharchuvannia", 1-2, 66-75 (in Ukrainian).

Volkova, A. (2015). Naukovo-etnohrafichne doslidzhennia osoblyvostei tekhnolohii strav 
ukrainskoi natsionalnoi kukhni. URL: http://journals.uran.ua/pathofscience/article/view/7298 4 (in Ukrainian).

Yehorov, B., Mardar, M., \& Bordun, T. (2014). Formuvannia spozhyvnykh vlastyvostei kharchovykh produktiv novoho pokolinnia shliakhom ekstruzii.
Khranenye y pererabotka zerna, 5(182), 64-67. URL: http://journals.uran.ua/index.php/2306-4498/article/ viewFile/106338/101495 (in Ukrainian).

Zhohlo, F. A., Popovych, V. P., Oliinyk, P. V., \& Shuryn, R. M. (1992). Vitaminonosni likarski roslyny: Dovidnyk. Lviv (in Ukrainian). 